\title{
Pengembangan Media Pembelajaran Matematika pada Materi Pecahan Berbasis Adobe Flash di Kelas V SD Negeri Kabupaten Indramayu
}

\author{
Ratna Dewi Lestyorini, Tommy Noviyanto \\ STKIP Pangeran Dharma Kusuma Indramayu \\ ratna.dewilestyorini@gmail.com
}

\section{Sejarah Artikel}

diterima 13/10/2019

\begin{abstract}
This background is the lack of understanding of students in the material of piece, especially in piece with denominators that are not worth. The purpose of this study is to determine the application and advisability of adobe flash based learning media in grade 5 on piece material. This research is research and development, include the problem, data collection, product design, design validation, design revision, trial product and use. The results of research can increase learning outcome of students, with an average pretest result of $63,31 \%$ and an average posttest result of $82,79 \%$. Based on the results of the research, the implication is that the adobe flash learning media can affect the learning outcomes of students, especially mathematics subject material of piece. This research can be used as input for teachers to improve self in the learning that has been done in order to improve student learning outcome.

Keywords: development, learning media, adobe flash.
\end{abstract}

\begin{abstract}
Abstrak
Latar belakang penelitian ini adalah kurangnya pemahaman peserta didik dalam materi pecahan, khususnya pada pecahan dengan penyebut yang tak senilai. Tujuan penelitian ini yaitu untuk mengetahui penerapan dan kelayakan media pembelajaran berbasis abobe flash di kelas $\mathrm{V}$ pada materi pecahan. Penelitian ini merupakan penelitian dan pengembangan (research and development), tahapannya meliputi masalah, pengumpulan data, desain produk, validasi desain, revisi desain, uji coba produk, dan uji coba pemakaian. Hasil penelitian ini dapat meningkatkan hasil belajar peserta didik, dengan rata-rata hasil pretes sebesar $63,31 \%$ dan rata-rata hasil postes sebesar $82,79 \%$. Berdasarkan hasil penelitian didapat implikasi yaitu media pembelajaran adobe flash dapat berpengaruh terhadap pencapaian hasil belajar peserta didik, khususnya pelajaran matematika materi pecahan. Hasil penelitian ini dapat digunakan sebagai masukan bagi guru untuk membenahi diri dalam pembelajaran yang telah dilakukan agar dapat meningkatkan hasil belajar peserta didik.

Kata kunci: pengembangan, media pembelajaran, adobe flash
\end{abstract}

e-ISSN 2581-1835

p-ISSN 2581-1843 


\section{PENDAHULUAN}

Pendidikan merupakan salah
satu faktor yang penting untuk
meningkatkkan kecerdasan dan
kualitas hidup manusia Indonesia
yang seiring dengan pekembangan
ilmu pengetahuan dan teknologi. Pemerintah berusaha untuk mewujudkan tujuan pendidikan tersebut dengan memperbaiki peraturan sistem pendidikan dengan pemberlakuan Kurikulum 2013. Penerapan Kurikulum 2013 atau yang dapat disingkat dengan kurtilas ini diwujudkan dalam model pembelajaran tematik integratif. "Pembelajaran tematik integratiif merupakan pendekatan pembelajaran yang mengintegrasiikan berbagai kompetensi dari berbagai mata pelajaran kedalam berbagai tema" (Kemendikbud, 2013: 9).

Tuntutan pendidikan nasional dengan kemajuan teknologi serta pengetahuan berpengaruh terhadap proses pendidikan dan pengajaran, sehingga berakibat tuntutan bagi tenaga pengajar harus mampu memanfaatkan dan menggunakan media. Penggunaan media pembelajaran merupakan salah satu alat bantu dalam proses belajar mengajar yang menarik dan inovatif bagi peserta didik. Media pembelajaran bermanfaat membantu dalam memudahkan proses kegiatan belajar mengajar, karena media pembelajaran dapat menghasilkan hal yang tidak dapat ditampilkan di dalam kelas. Dalam kegiatan belajar mengajar yang menganut pembelajaran aktif, kreatif, efektif dan menyenangkan, sehingga guru tidak dapat melepaskan diri dari media pembelajaran (Said, 2017).

Pendidikan

matematika merupakan ilmu universal yang mendasari perkembangan teknoligi moderen, mempunyai peran penting dalam berbagai disiplin dan mengembangkan daya pikir manusia (Ibrahim dan Suparni: 2008: 35). Berdasarkan observasi yang telah dilakukan, didapat bahwa permasalahan pada peserta didik adalah kurang menguasai dan memahami mata pelajaran matematika, dikarenakan peserta didik yang kurang berminat terhadap mata pelajaran matematika. Pada materi pecahan, peserta didik mengalami kesulitan dalam penyamaan penyebut atau mencari kelipatan persekutuan kecil. Dengan adanya permasalahan ini, maka perlu untuk dilakukan pengembangan media yang berbasis komputer salah satu contohnya adalah adobe flash, agar peserta didik mempunyai peran aktif dalam kegiatan belajar mengajar.

Peserta didik Sekolah Dasar (SD) pada dasarnya berusia antara tujuh sampai dua belas tahun, menurut Piaget usia terebut berada difase operasional konkrit, yang pada fase ini kemampuan yang dimuncul adalah kemampuan dalam proses berpikir untuk menjalankan kaidah logika meskipun masih terikat dengan objek yang mempunyai sifat konkrit. Menurut Suherman (dalam Achmad dan Nur, 2018), pembelajaran matematika merupakan proses dimana siswa secara aktif mengkontruksi melalui pengalaman yang telah mereka miliki sebelumnya.

Berdasarkan hal tersebut, perlu adanya media pembelajaran yang dapat membangkitka motivasi belajar peserta didik serta menambah tingkat pemahaman peserta didik terhadap materi pembelajaran. Media atau alat bantu mengajar yang digunakan 
disesuaikan dengan kompetensi dasar serta tujuan pembelajaran. Dalam memilih media pembelajaran, guru juga harus mengikuti perkembangan yang ada saat ini termasuk perkembangan teknologi. Teknologi yang semakin berkembang pesat dan semakin dekat dengan anak-anak tentu akan mampu memberikan ketertarikan bagi mereka. Teknologi mempunyai peranan penting dalam menyampaikan informasi baik dalam gambar, bentuk teks, ataupun suara kepada pengguna diseluruh dunia. Salah satu contoh perkembangan teknologi dalam bentuk media adalah multimedia.

Multimedia merupakan salah satu wujud media pembelajaran yang mempunyai keunggulan. Dengan multimedia, guru dapat menampilkan lebih banyak objek dalam bentuk gambar dengan suara. Aplikasi yang dapat dipraktekan untuk membuat multimedia pembelajaran adalah Adobe Flash. Adobe flash adalah aplikasi yang dimanfaatkan untuk merancang desain dan mengembangkan media persentasi atau aplikasi lain yang membutuhkan sarana interaksi dengan penggunanya..

Berdasarkan pengamatan peneliti software Adobe flash professional merupakan salah satu dari berbagai program dalam pembuatan media pembelajaran. Adobe flash mempunyai kelebihan, yaitu mampu menampilkan multimedia, teks, gabungan antar grafis, animasi, dan suara. Kelebihan yang dimiliki software Adobe flash CS6 proffesional dapat lebih mudah dipahami bagi peserta didik dalam menjelaskan konsep matematika, salah satu contohnya adalah pecahan. Pembelajaran matematika di lingkungan Sekolah Dasar (SD) merupakan mata pelajaran yang wajib diberikan pada peserta didik SD. Pada awal kegiatan belajar mengajar diawali dari guru yang memberikan pemahaman konsep menggunakan alat atau benda konkrit terlebih dulu. Menurut Heruman (2010: 1), siswa SD umumnya berkisar antara 6 atau 7 tahun, sampai 12 atau 13 tahun. Menurut Piaget dalam Heruman (2010: 1), mereka berada pada fase operasional konkrit. Kemampuan yang terlihat dalam fase ini adalah kemampuan pada proses berpikir untuk mengoperasikan kaidah-kaidah logika, meskipun masih terikat dengan objek yang bersifat konkrit.

\section{METODE}

Metode penelitian dan pengembangan atau dalam bahasa inggrisnya Research and Development ( $R$ \& $D$ ) adalah metode penelitian yang digunakan untuk menghasilkan produk tertentu, dan menguji keefektifan produk tersebut. (Sugiyono, 2013: 407). Penelitian ini mengembangkan media pembelajaran dalam bentuk Compact Disc (CD) interaktif. Teknik analisis data yaitu melakukan analisis produk yang akan dikembangkan; mengembangkan produk awal; walidasi ahli dan revisi; uji coba lapangan skala kecil dan revisi produk; dan uji coba lapangan skala besar dan produk akhir.

Instrumen penelitian yang digunakan adalah lembar observasi, lembar validasi, lembar pedoman wawancara, agket atau kuesioner dan tes. Lembar observasi digunakan untuk mengukur tingkahlaku yang dapat diamati dalam keadaan 
sebenarnya. Lembar validasi digunakan untuk mengukur validasi isi dan validitas konstruk dari bahan ajar yang dikembangkan. Tes digunakan untuk mengetahui kelayakan panggunaan bahan ajar sebagai sumber belajar peserta didik kelas $\mathrm{V}$ sekolah dasar negeri. Adapun tes yang dilaksanakan berupa pretes dan postes. Pemilihan populasi adalah sekolah dasar negeri di kecamatan Sliyeg, dengan sampel enam sekolah dasar negeri di kecamata Sliyeg kabupaten Indramayu.

\section{PEMBAHASAN}

Penerapan media pembelajaran yang berbasis multimedia ini dapat diterapkan dengan baik, begitu juga dengan peserta didik yang ikut aktif dalam kegiatan belajar mengajar. Sehingga suasana di dalam kelas menjadi lebih hidup dan tidak membuat peserta didik menjadi jenuh.
Hasil penelitian pada peserta didik kelas $\mathrm{V}$ sekolah dasar yang ada di Kecamatan Sliyeg Kabupaten Indramayu dilakukan dengan mengadakan pretes dan postes kepada setiap peserta didik. Hasil nilai yang diperoleh dari pretes dan postes disajikan pada Tabel 2 berikut:

Tabel 1.

Data Nilai Hasil Belajar Pretes dan Postes

\begin{tabular}{|c|c|c|c|}
\hline \multirow{2}{*}{ No } & \multirow{2}{*}{ Nilai } & \multicolumn{2}{|c|}{ Jumlah Peserta Didik } \\
\hline & & Pretes & Postes \\
\hline 1 & 0 & 2 & 0 \\
\hline 2 & 1 & 2 & 0 \\
\hline 3 & 2 & 4 & 0 \\
\hline 4 & 3 & 13 & 0 \\
\hline 5 & 4 & 12 & 0 \\
\hline 6 & 5 & 25 & 0 \\
\hline 7 & 6 & 25 & 0 \\
\hline 8 & 7 & 28 & 1 \\
\hline 9 & 8 & 35 & 129 \\
\hline 10 & 9 & 19 & 35 \\
\hline 11 & 10 & 7 & 7 \\
\hline
\end{tabular}

Tabel 2.

Rata-Rata Nilai Pretes dan Postes

\begin{tabular}{lcc}
\hline & Pretes & Postes \\
\hline Jumlah Peserta Didik & 172 & 172 \\
Rata-Rata & $63,31 \%$ & $82,79 \%$ \\
\hline
\end{tabular}

Tabel 3.

Persentase Butir Soal

\begin{tabular}{lcccccccccc}
\hline & \multicolumn{11}{c}{ Rata-Rata } \\
\hline No Soal & 1 & 2 & 3 & 4 & 5 & 6 & 7 & 8 & 9 & 10 \\
Pretes (\%) & 88 & 47 & 70 & 81 & 49 & 63 & 88 & 53 & 63 & 47 \\
Postes (\%) & 88 & 78 & 81 & 85 & 83 & 77 & 95 & 81 & 81 & 79 \\
\hline
\end{tabular}


Berdasarkan data pada Tabel 2. bahwa rata-rata nilai yang diperoleh pada saat pretes adalah $63,31 \%$ dengan jumlah peserta didik 172. Sedangkan rata-rata nilai yang diperoleh pada saat postes adalah $82,79 \%$ dengan jumlah peserta didik 172. Ini berarti ada pengaruh media pembelajaran berbasis adobe flash khususnya materi pecahan pada mata pelajaran matematika, peserta didik lebih mengerti dan lebih aktif dalam mengerjakan soal latihan.

Berdasarkan Tabel 3. Tingkat kesulitan pada saat pretes ada 4 nomor yaitu pada soal nomor 2, 5, 8, dan 10 , dengan rata-rata pada soal nomor 2 adalah 47, rata-rata soal nomor 5 adalah 49, soal nomor 8 adalah 53, dan untuk rata-rata soal nomor 10 adalah 47. Untuk soal nomor 3, 6, dan 9 termasuk dalam kategori soal yang sedang. Rata-rata secara berurutan adalah 70,63 , dan
63. Sedangkan untuk tingkat yang mudah ada 3 soal, yaitu nomor 1, 4, dan 7 dengan masing-masing rataratanya adalah 88,81 , dan 88 . Pada Tabel 2 untuk tingkat kesulitan soal postes adalah kriteria yang mudah ada semua nomor soal dengan ratarata secara berurutan mulai dari soal nomor 1 sampai dengan soal nomor 10 adalah $88,78,81,85,83,77,5$, 81, 81, dan 79. Ini berarti setelah dilaksanakan model pembelajaran memakai adobe flash bagi peserta didik kelas V SDN khususnya di wilayah Sliyeg dapat diterapkan untuk kegiatan belajar mengajar pada saat pembelajaran matematika. Dari hasil tersebut untuk rata-rata yang diperoleh pada saat pretes sudah ada dua indikator yang di atas Kriteria Ketuntasan Minimal (KKM), sedangkan rata-rata yang diperoleh untuk postes sudah di atas KKM semua.

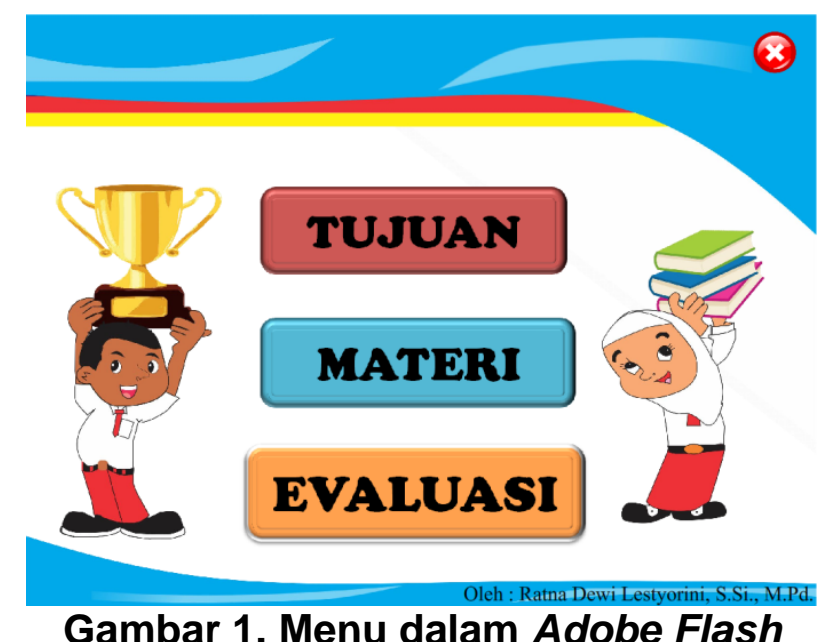

Program adobe flash ini berpengaruh besar pada keaktifan peserta didik, salah satu menu dalam program adobe flash ini ada pada Gambar 1.

Gambar 1. Bertemakan menu yang akan dipilih, seperti Tujuan Pembelajaran, Materi Pecahan, dan Evaluasi. Pada menu tujuan berisikan tentang tujuan pembelajaran dari mata pelajaran yang disampaikan yaitu matematika dengan materi pecahan. Pada menu Materi, menjelaskan beberapa materi tentang pecahan, seperti penjumlahan pecahan biasa/ pecahan campuran, pengurangan pecahan biasa/ pecahan campuran, perkalian pecahan biasa/ pecahan 
campuran, dan pembagian pecahan biasa/ pecahan campuran.

Di dalam menu penjumlahan terdapat uraian materi tentang pecahan biasa yang senilai dan tak senilai, serta dilengkapi juga dengan contoh soal dan pembahasan. Pada menu pengurangan terdapat ulasan materi tentang pengurangan senilai dan tak senilai, serta dilengkapi pula dengan contoh dan pembahasannya. Untuk menu perkalian dan pembagian senilai atau tak senilai, baik pecahan biasa atau pecahan campuran,juga dilengkapi dengan contoh soal dan pembahasan. Dengan adanya contoh soal dan pembahasan ini ditujukan agar peserta didik dapat memahami dan mendalami lagi tentang penjelasan pada setiap materi.

Pada Gambar 3. Menu Evauasi, berisi tentang evaluasi soal pilihan ganda dan diakhir soal akan terdapat jumlah benar dan salah soal yang telah dikerjakan beserta pembahasannya. Adanya menu evaluasi ini dimanfaatkan agar peserta didik dapat mngukur kemampuan yang telah didapat setelah pembelajaran memakai adobe flash khususnya pada mata pelajaran matematika. Evaluasi yang didapat setelah memakai media adobe flash ini bagus dengan rata-rata yang didapat sudah di atas KKM. Kekurangan dalam penelitian ini adalah peserta didik tidak memakai komputer atau laptop sendiri, media yang disediakan hanya memakai infokus dan peserta didik menjawabnya diselembar kertas. Meskipun begitu antusias dari peserta didik sangat positif dan baik.

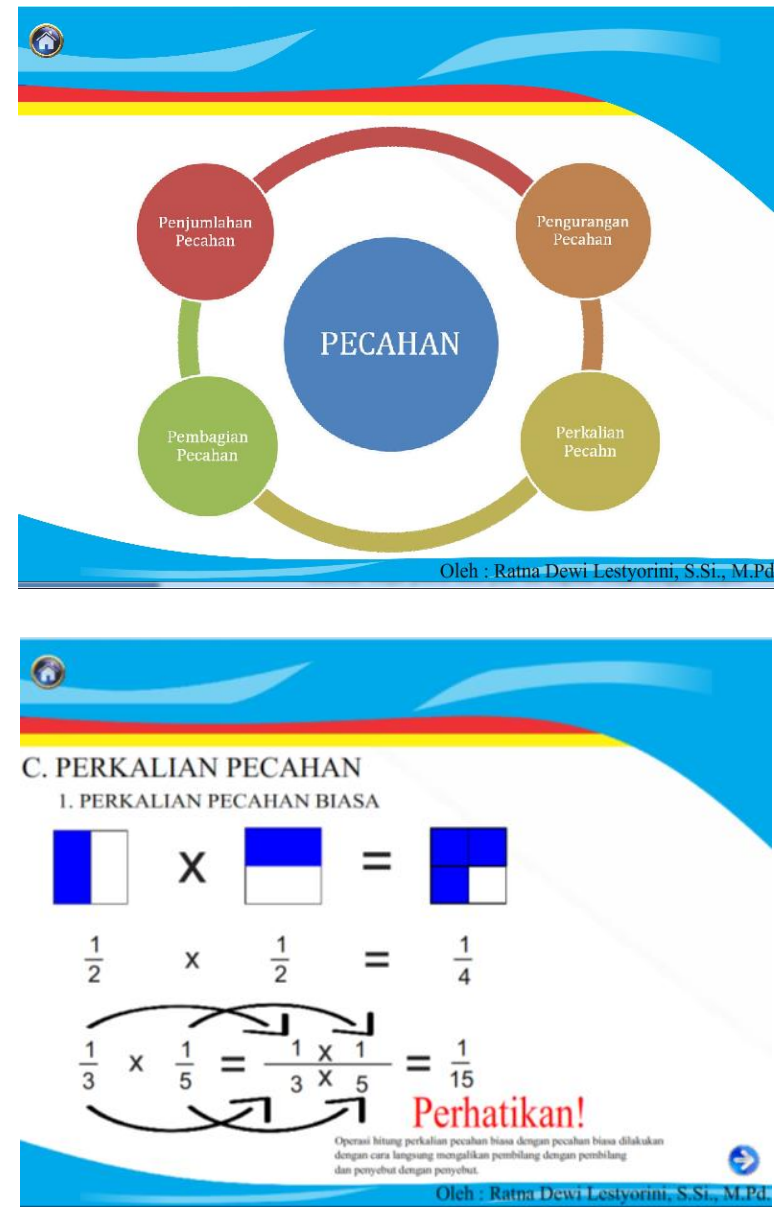

Gambar 2. Menu Materi 


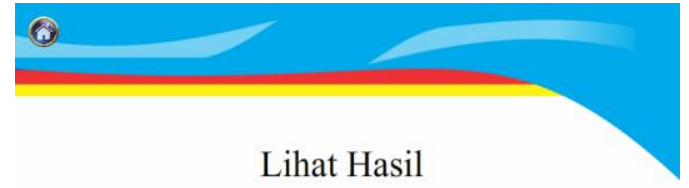

Jika ingin melihat hasil klik tombol dibawah ini

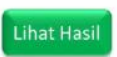

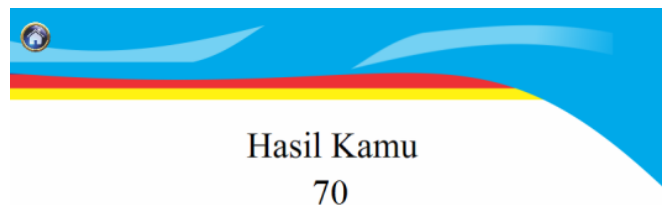

Benar 7

Salah

Jika kamu ingin mengulang silahkan klik tombol ulang

Ulang

\section{Gambar 3. Menu Evaluasi}

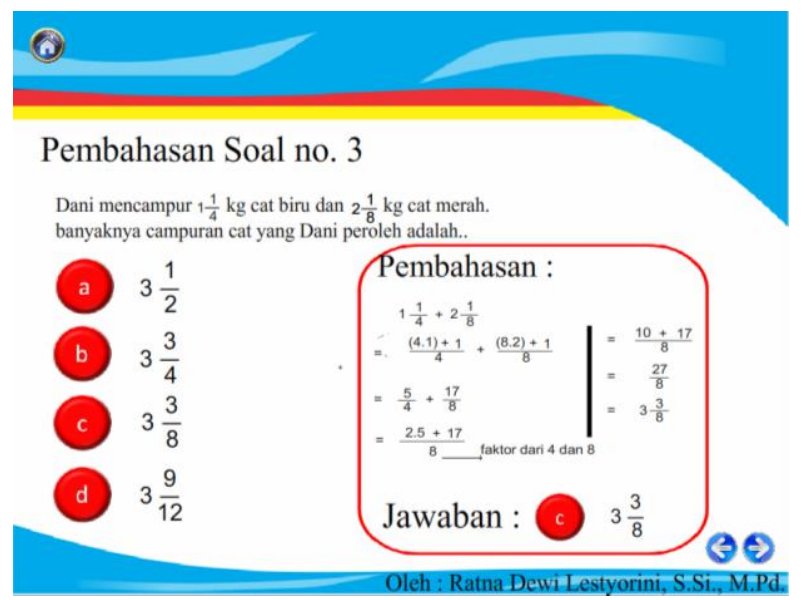

Gambar 4. Menu Pembahasan

Pada Gambar 4, menjelaskan tentang pembahasan dari evaluasi pembelajaran pada materi pecahan. Dengan adanya pembahasan ini, maka peserta didik dapat mengetahui letak kesalahan pada saat mengerjakan soal latihan.

Keaktifan belajar peserta didik pada saat kegiatan belajar mengajar menjadi lebih hidup dan mudah dipahami oleh peserta didik. Peserta didik mulai berani mengerjakan latihan soal di depan atau di papan tulis. Dengan adanya program adobe flash ini peserta didik jadi lebih terbantu, apalagi dilengkapi dengan latihan soal dan pembahasannya. Dan setiap halaman dilengkapi dengan tombol home atau kembali kemenu utama, tanpa harus kembali satu persatu membuka menu setiap halaman.
Penelitian ini bertujuan untuk mengembangkan media pembelajaran matematika materi pecahan berbasis adobe flash dengan mengukur hasil belajar dalam skala kecil terlebih dahulu, kemudian melakukan pengembangan draf produk media pembelajaran melalui proses belajar mengajar di dalam kelas V. Pada uji pertama peserta didik merasa bersemangat dan aktif untuk mempelajari materi pecahan berbasis adobe flash ini. Antusias peserta didik terlihat ketika melihat animasi yang ditampilkan pada layar infokus. Diakhir pembelajaran guru kelas dan peserta didik memberikan masukan untuk dilakukan revisi akhir.

Media pembelajaran berbasis adobe flash merupakan media pembelajaran interaktif yang dapat 
digunakan salam proses belajar mengajar mata pelajaran matematika. Penggunaan media pembelajaran berbasis teknologi dalam proses pembelajaran tidak lagi digunakan disebabkan keterbatasan kemampuan guru dalam mengembangkan media pembelajaran berbasis teknologi (Francisca, 2018).

Pada uji akhir, guru dan peserta didik berpendapat bahwa media berbasis adobe flash ini membantu peserta didik untuk lebih mudah memahami penjelasan dari materi pecahan, karena materi yang ditampilkan lebih menarik dan dilengkapi dengan evaluasi serta pembahasan dari evaluasi tersebut. Media berbasis adobe flash mata pelajaran matematika layak untuk digunakan dalam kegiatan pembelajaran. Maiata, dkk (2018) berpendapat bahwa media pembelajaran menggunakan adobe flash berbasis metakognisi yang dikembangkan leh peneliti layak digunakan dalam pembelajaran materi fungsi komposisi dan fungsi invers untuk meningkatkan motivasi.

\section{SIMPULAN}

Berdasarkan hasil penelitian yang telah dilakukan, maka didapatkan kesimpulan bahwa pembelajaran berbasis adobe flash pada materi pecahan kelas $\mathrm{V}$ sekolah dasar negeri di Kecamatan Sliyeg Kabupaten Indramayu meningkatkan aktivitas dan hasil belajar peserta didik, dengan rata-rata hasil pretes sebesar $63,31 \%$ dan rata-rata hasil postes sebesar $82,79 \%$. Implikasi hasil penelitian ini yaitu media pembelajaran adobe flash dapat berpengaruh terhadap pencapaian hasil belajjar peserta didik, khususnya pada materi pecahan.

\section{DAFTAR PUSTAKA}

Ahmad Baroqah \& Nur Rosit. (2018). Pengembangan Media

Pembelajaran Interaktif

Pelajaran Matematika Mengenal Bangun Ruang dengan Metoe Inkuiri untuk Siswa Tingkat Dasar. Vol. VI. No 1. Jurnal Khatulistiwa Informatika.

Azhar, Arsyad. (2011). Media Pembelajaran. Jakarta: Raja Grafindo Persada.

Borg, W. R., Gall M. D \& Gall. J. P. 1983. Education research: an introduction. (7thEd). New York: Pearson Education. Inc.

Djiwandono, Sri Esti Wuryani. (2014). Psikologi Pendidikan. Bandung: Grasindo.
Francisca. (2018). Pengembangan Media Pembelajaran Matematika Berbasis Adobe Flash CS3 Professional pada Materi Kubus dan Balok Ditinjau dari Prestasi Belajar dan Kepercayaan Diri Siswa SMP Negeri 1 Ngawen. Skripsi. (Yogyakarta: Universitas Sanata Dharma).

Heruman. (2010). Model Pembelajaran Matematika. Bandung: Remaja Rosdakarya. Ibrahim, Suparni. (2008). Pembelajaran Matematika Teori dan Aplikasinya. Yogyakarta: Suka-Press.

Kemendikbud. (2013). Peraturan Menteri Pendidikan Nasional dan 
Kebudayaan RI No 67 Tahun 2013 tentang standar proses.

Maiata, Darmadi \& Wasilatul. (2018). Pengembangan Pembelajaran Media Flash Berbasis Metakognisi untuk Meningkatkan Motivasi Belajar Matematika. Vol 8 No 1 Edumatica: Jurnal Pendidikan Matematika.

Said Alwi. (2017). Problematika Guru dalam Pengembangan Media Pembelajaran. Vol. 8 No. 2. Itqam.

Sugiyono. (2013). Metode Penelitian Pendidikan:

Pendekatan Kuantitatif, Kualitatif, dan $R \& D$. Bandung: Alfabeta
Sukirman. (2012). Pengembangan Media Pembelajaran. Yogyakarta: Pustaka Insan Madani.

Susanto, A. (2013). Teori Belajar dan Pembelajaran di Sekolah Dasar. Jakarta: Prenada Media Grup.

Tim Divisi Penelitian dan Pengembangan. (2007). Panduan Lengkap Adobe Flash CS3 Professional. Yogyakarta: Andi Offset. 